\title{
Structural evaluation of sugar cane bagasse steam pretreated in the presence of $\mathrm{CO}_{2}$ and $\mathrm{SO}_{2}$
}

\author{
Roberta Cristina Novaes Reis Corrales ${ }^{1}$, Fabiana Magalhães Teixeira Mendes ${ }^{1}$, Clarissa Cruz Perrone ${ }^{1}$, \\ Celso Sant'Anna ${ }^{2,3}$, Wanderley de Souza ${ }^{2,3}$, Yuri Abud ${ }^{2}$, Elba Pinto da Silva Bon ${ }^{4}$ and Viridiana Ferreira-Leitão ${ }^{1,4^{*}}$
}

\begin{abstract}
Background: Previous studies on the use of $\mathrm{SO}_{2}$ and $\mathrm{CO}_{2}$ as impregnating agent for sugar cane bagasse steam treatment showed comparative and promising results concerning the cellulose enzymatic hydrolysis and the low formation of the inhibitors furfural and hydroxymethylfurfural for the use of $\mathrm{CO}_{2}$ at $205^{\circ} \mathrm{C} / 15 \mathrm{~min}$ or $\mathrm{SO}_{2}$ at $190^{\circ} \mathrm{C} / 5 \mathrm{~min}$. In the present study sugar cane bagasse materials pretreated as aforementioned were analyzed by scanning and transmission electron microscopy (SEM and TEM), X-Ray Diffraction (XRD) and Infrared (FTIR spectroscopy) aiming a better understanding of the structural and chemical changes undergone by the pretreated materials.
\end{abstract}

Results: SEM and TEM data showed that the structural modifications undergone by the pretreatment with $\mathrm{CO}_{2}$ were less pronounced in comparison to that using $\mathrm{SO}_{2}$, which can be directly related to the combined severity of each pretreatment. According to XRD data, untreated bagasse showed, as expected, a lower crystallinity index $(\mathrm{Cl}=48.0 \%)$ when compared to pretreated samples with $\mathrm{SO}_{2}(\mathrm{Cl}=65.5 \%)$ or $\mathrm{CO}_{2}(\mathrm{Cl}=56.4 \%)$, due to the hemicellulose removal of $68.3 \%$ and $40.5 \%$, respectively. FTIR spectroscopy supported SEM, TEM and XRD results, revealing a more extensive action of $\mathrm{SO}_{2}$.

Conclusions: The SEM, TEM, XRD and FTIR spectroscopy techniques used in this work contributed to structural and chemical analysis of the untreated and pretreated bagasse. The images from SEM and TEM can be related to the severity of $\mathrm{SO}_{2}$ pretreatment, which is almost twice higher. The crystallinity index values obtained from XRD showed that pretreated materials have higher values when compared with untreated material, due to the partial removal of hemicellulose after pretreatment. FTIR spectroscopy supported SEM, TEM and XRD results. $\mathrm{CO}_{2}$ can actually be used as impregnating agent for steam pretreatment, although the present study confirmed a more extensive action of $\mathrm{SO}_{2}$.

Keywords: Sugar cane bagasse, $\mathrm{CO}_{2}$ and $\mathrm{SO}_{2}$ steam pretreatment, SEM and TEM microscopy, XRD and FTIR spectroscopy

\section{Background}

There is a growing urgency to develop novel bio-based products and other innovative technologies that can overcome the widespread dependence on fossil fuels [1]. Unlike gasoline, ethanol is a renewable energy source produced through fermentation of sugar. In Brazil, ethanol is produced largely from sugar cane juice, known as

\footnotetext{
* Correspondence: viridiana.leitao@int.gov.br

${ }^{1}$ National Institute of Techonology, Ministry of Science and Techonology, Av. Venezuela, 82, sala 302, CEP 20081-312 Rio de Janeiro - RJ, Brazil

${ }^{4}$ Department of Biochemistry, Institute of Chemistry, Federal University of Rio de Janeiro, Av. Athos da Silveira Ramos, 149, bloco A, llha do Fundão, CEP: 21941-909 Rio de Janeiro - RJ, Brazil

Full list of author information is available at the end of the article
}

first generation (1G) ethanol. The residual lignocellulosic biomass from the $1 \mathrm{G}$ ethanol industry (sugar cane bagasse and leaves) is, presently, for a collection of reasons, the most promising resource for the production of lignocellulosic (2G) ethanol [2]. However, although the sugarethanol industry generates bagasse in large quantities during the process of extraction of the sugar cane juice it is mostly used for co-generation, accounting for approximately $3 \%$ of the electricity available in Brazil [3].

Lignocellulosic biomass is mainly composed of cellulose, hemicellulose and lignin. The predominant component of lignocellulosic biomass is cellulose, a linear $\beta(1,4)$-linked chain of glucose molecules. It is non-toxic, renewable, biodegradable, modifiable and has great potential as an 
excellent industrial material $[4,5]$. The elementary fibrils are composed of crystalline and amorphous regions. Hemicelluloses are made up of C5 and C6 sugar, such as xylose, arabinose, galactose, glucose and mannose. Lignin accounts for about one fourth of the lignocellulosic biomass and is the third most abundant biopolymer only after cellulose and hemicellulose.

According to Fengel and Wegener [6], four elementary fibrils of cellulose are held together by a monolayer of hemicellulose, which generate $25 \mathrm{~nm}$ wide thread-like structures that are enclosed in a matrix of hemicellulose and lignin (associated with each other through physical interactions and covalent bonds).

The main steps for ethanol production from lignocellulosic biomass are pretreatment, hydrolysis, fermentation and distillation/purification. The pretreatment should enhance the fiber accessibility and consequently facilitate the subsequent steps of enzymatic hydrolysis and fermentation [7].

The raw material pretreatment step could represent up to $20 \%$ of the total costs of cellulosic ethanol production [8]. According to Galbe and Zacchi [9], an effective pretreatment should (a) improve cellulose digestibility; (b) produce low concentrations of degradation products derived from sugars and lignin; and (c) have a low energy demand.

Previous studies on steam pretreatment of bagasse employed $\mathrm{CO}_{2}$ as impregnating agent to replace the traditionally used $\mathrm{SO}_{2}$ [10]. The use of $\mathrm{CO}_{2}$ was previously investigated in order to explore some advantages of this gas over $\mathrm{SO}_{2}$, such as high availability in the firstgeneration ethanol plants, low toxicity, low corrosivity and low occupational risk [10,11]. Although the use of $\mathrm{CO}_{2}$ provided equivalent results in comparison to those obtained when $\mathrm{SO}_{2}$ was used as impregnating agent, higher temperatures or longer times were necessary. Comparative results concerning glucose release and inhibitors formation (furfural and hydroxymethylfurfural HMF) from steam pretreated bagasse were obtained under the conditions: $205^{\circ} \mathrm{C} / 15 \mathrm{~min}$ using $\mathrm{CO}_{2}$ or $190^{\circ} \mathrm{C} / 5 \mathrm{~min}$ using $\mathrm{SO}_{2}$. As previously reported by authors [10], the use of $\mathrm{SO}_{2}$ resulted in $79.7 \%$ of glucose after enzymatic hydrolysis and provided the formation of $0.80 \mathrm{~g} / 100 \mathrm{~g}$ of furfural and $0.18 \mathrm{~g} / 100 \mathrm{~g}$ of HMF (dry bagasse). When $\mathrm{CO}_{2}$ was employed, the yield of glucose reached $86.6 \%$ and the values for furfural $(0.9 \mathrm{~g} / 100 \mathrm{~g})$ and HMF $(0.2 \mathrm{~g} / 100 \mathrm{~g})$ were very similar to those reported for $\mathrm{SO}_{2}$

FTIR spectroscopy and electron microscopy have been used for the analysis of structural and morphological modifications in the biomass after pretreatment [12-14]. The present work evaluated structural and chemical changes of $\mathrm{SO}_{2}$ and $\mathrm{CO}_{2}$ steam pretreated sugar cane bagasse in comparison to the untreated material using electron microscopy, X-ray diffraction (XRD) and infrared spectroscopy (FTIR).

\section{Results and discussion}

\section{Scanning electron microscopy (SEM) and transmission} electron microcopy (TEM)

The use of scanning electron microscopy as an analytical technique proved to be of great importance and versatility for studying the biomass structure. Figure 1 shows the morphological characteristics of the steam pretreated bagasse in the presence of $\mathrm{CO}_{2}$ or $\mathrm{SO}_{2}$ as well as of the untreated material, obtained by scanning electron microscopy (SEM).

Untreated bagasse sample (Figure 1A, B, C) presents a rigid and compact morphology, while the ones submitted to pretreatment with $\mathrm{SO}_{2}$ (Figure 1D, E, F) or $\mathrm{CO}_{2}$ (Figure 1G, H, I) exhibited a more disorganized morphology, with greater exposure of the fibers.

After pretreatment, the most exposed cell wall structure allows for a greater accessibility to hydrolytic enzymes, which facilitates the hydrolysis of lignocellulosic biomass.

Transmission electron microscopy (TEM) has been used as a suitable method to determine the effect of pretreatment within the plant cell wall [15]. TEM images of untreated sugar cane bagasse clearly showed that the primary cell wall $(\mathrm{PCW})$, secondary cell wall $(\mathrm{SCW})$ and middle lamella (ML) were well preserved (Figure 2A, B). These structures were bonded strongly together giving rise to a typical highly compact architecture of cell walls. As it is a thicker and more rigid structure in the bagasse, the SCW, where cellulose microfibrils are arranged in parallel position, is responsible for cell wall integrity (Figure 2B). The pretreated $\mathrm{CO}_{2}$ samples show, in the cell wall, large pores with different size and shape (Figure 2C, D). Remarkably, most of the pores were formed in the outer region of the cell wall. When $\mathrm{SO}_{2}$ was used as impregnating agent, the secondary cell wall, especially the outer region, was also severely disrupted leading to the appearance of large irregular shaped pores (Figure 2E, F) as a result of partial solubilization of ultrastructural cell wall components. Similar results were recently reported by Chundawat and co-workers [15] in corn stover after ammonia fiber expansion (AFEX) treatment.

The AFEX pretreatment strategy revealed that cellulose hydrolysis increased roughly five-fold when compared to untreated samples. In addition, when both $\mathrm{CO}_{2}$ and $\mathrm{SO}_{2}$ were employed, coalescent particles with round or elongated shapes were found in the cell wall (Figure 2D, F). They seem to be formed by the process of coalescence of cell wall matrix components (hemicelluloses and lignin). The change in cell wall morphology observed when bagasse was pretreated with either $\mathrm{CO}_{2}$ or $\mathrm{SO}_{2}$ result in the increase of the cell wall porosity. At nanoscale, the limited cell wall matrix porosity is considered an important factor that impairs cellulase penetration and accessibility to cellulose fibrils, therefore, contributing to biomass recalcitrance $[16,17]$. 


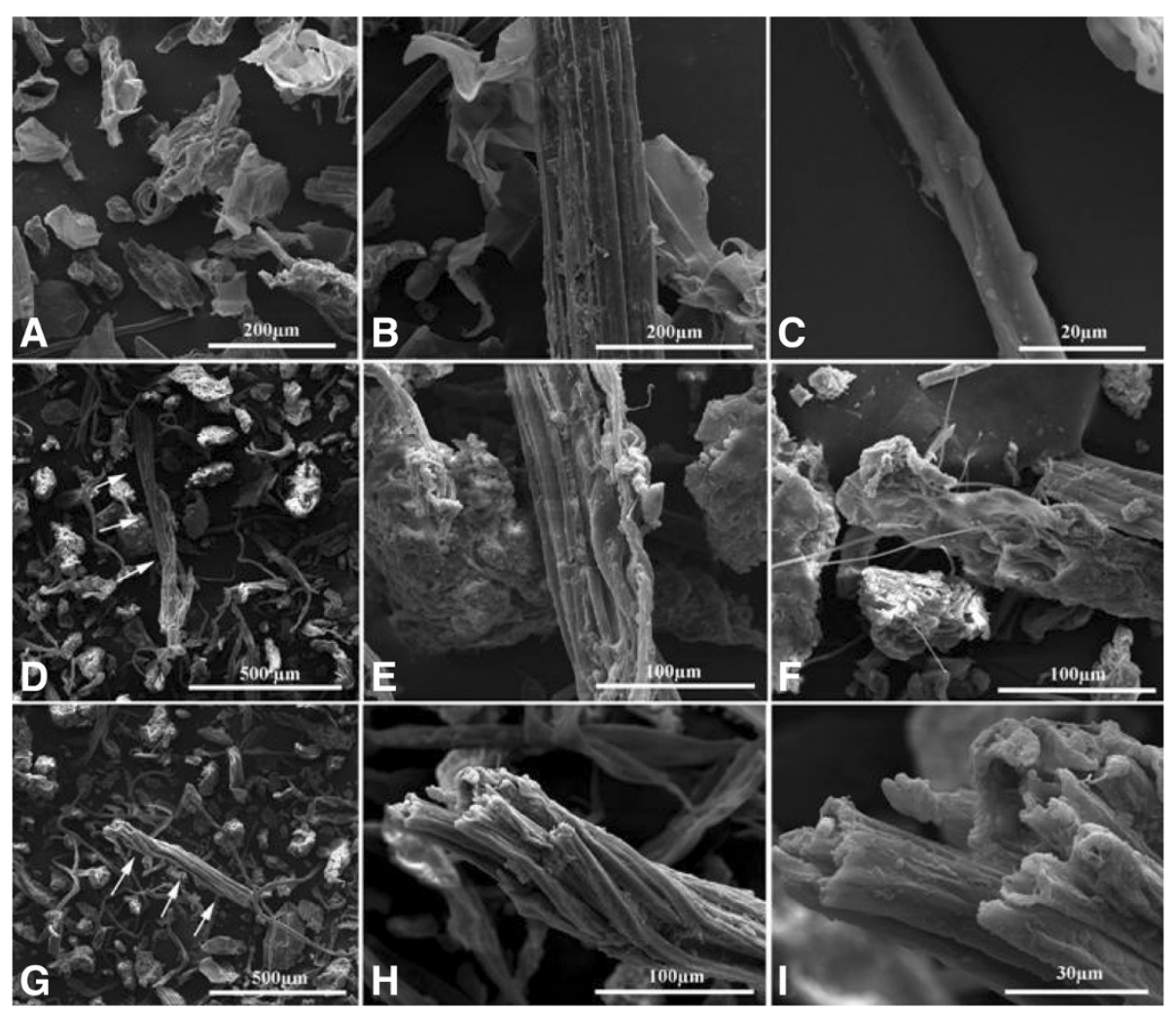

Figure 1 SEM images of untreated sugar cane bagasse (A, B and C); (A) General view of the sample showing the fibers (mainly); (B and C) higher magnification image of fiber surface; SEM images of sugar cane bagasse pretreated with $\mathrm{SO}_{2}\left(190^{\circ} \mathrm{C} / 5 \mathrm{~min}\right)(\mathbf{D}$, E and $\mathbf{F})$; (D) General view of the sample showing the fibers (mainly); (E) higher magnification image of fiber surface (arrows in the $\mathbf{D}$ image); (F) higher magnification image of fiber surface extremity; SEM images of the bagasse pretreated with $\mathrm{CO}_{2}\left(205^{\circ} \mathrm{C} / 15 \mathrm{~min}\right)(\mathbf{G}, \mathbf{H}$ and $\mathbf{I}) ;(\mathbf{G})$ General view of the sample showing the fibers (mainly); (H) and (I) higher magnification images of fiber surface (arrows in the $\mathbf{G}$ image).

Data from SEM and TEM showed that both pretreatments were effective with respect to structural changes, increasing the surface exposure of the bagasse samples. However, the morphology of $\mathrm{CO}_{2}$ pretreated material is more preserved than that of the $\mathrm{SO}_{2}$ material. This result can be directly related to the higher combined severity for the pretreatment using $\mathrm{SO}_{2}$ (1.7), when compared to combined severity of the pretreatment with $\mathrm{CO}_{2}(0.9)$ as impregnating agent. It is important to emphasize that the combined severity factor [18] takes into account besides time and temperature of the steam pretreatment, the acidity generated in the reaction media by the formation of sulfuric and carbonic acid and the release of organic acids, such as acetic acid from the raw material, as indicated by the $\mathrm{pH}$ drop after pretreatment $\left(\mathrm{pH} 1.7\left(\mathrm{SO}_{2}\right) ; \mathrm{pH} 3.8\left(\mathrm{CO}_{2}\right)\right)$ [10].

\section{X-ray diffraction (XRD)}

Figure 3 shows diffractograms of untreated bagasse (A) and sugar cane bagasse pretreated with $\mathrm{SO}_{2}$ (B) or $\mathrm{CO}_{2}$ (C). As can be observed, all samples exhibit typical cellulose diffraction peaks, where the highest peak corresponds to the 002 crystallographic planes. The crystallinity index was calculated according to Equation 1 (Methods session). The untreated sugar cane bagasse showed a lower crystallinity $(\mathrm{CI}=48.0 \%)$ when compared to samples pretreated with $\mathrm{SO}_{2}(\mathrm{CI}=65.5 \%)$ and $\mathrm{CO}_{2}(\mathrm{CI}=56.4 \%)$. Many studies indicate that there is an increase in the value of this index when the biomass is subjected to pretreatment by steam explosion [19]. The phenomenon is due mainly to the removal of a certain amount of lignin and hemicellulose (amorphous substances) and not necessarily due to changes in the crystalline structure of the biomass.

As expected the crystallinity index for the bagasse pretreated with $\mathrm{SO}_{2}(65.5 \%)$ was higher than that of $\mathrm{CO}_{2}$ pretreated bagasse $(56.4 \%)$. Indeed, it was observed a more effective removal of hemicellulose to the liquid fraction (63.8\%: 7.0\% xylose as oligomers and 56.8\% of monomeric xylose) using the $\mathrm{SO}_{2}$ steam pretreatment than that using $\mathrm{CO}_{2}$ that showed $40.5 \%$ hemicellulose removal : (21.5\%) of xylose in oligomeric form and $19.0 \%$ in monomeric form) [10]. In this work, the increase of the crystallinity index in the pretreated samples is explained by the partial removal of hemicellulose fraction. The amount of glucose released 


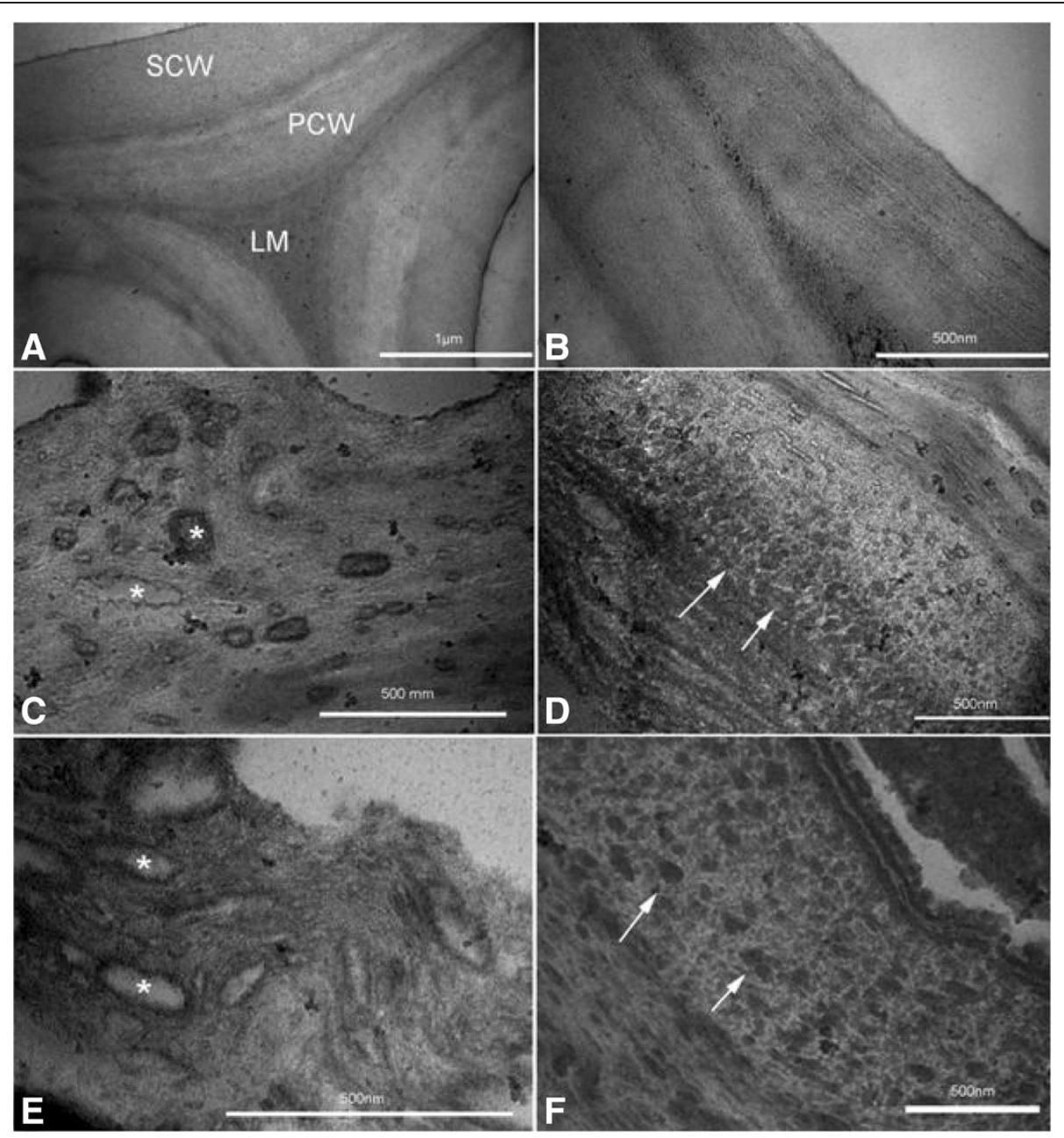

Figure 2 TEM images of untreated bagasse showing the following cell wall layers: primary cell wall (PCW), secondary cell wall (SCW) and middle lamella (ML) (Fig. A). Fig. B - higher magnification of SCW showing the cellulose microfibrils orientation. Fig. $\mathbf{E}, \mathbf{F}-\mathrm{SO}_{2}\left(190^{\circ} \mathrm{C} / 5 \mathrm{~min}\right)$ pretreated cell wall. Large pores with distinct size and shape are observed (Fig. C, asterisks). Compaction of cell wall matrix was visualized forming round and elongated structures (Fig. D, arrows). Fig. C, D $-\mathrm{CO}_{2}\left(205^{\circ} \mathrm{C} / 15 \mathrm{~min}\right)$ pretreated cell wall. After treatment pores (Fig. E, asterisks) and structures formed by compaction of cell wall matrix (Fig. F, arrows) are seen spread th the outer region of secondary cell wall.

from cellulose (amorphous region) was not relevant in the pretreatment step.

The high-pressure steam modifies the plant cell wall structure, yielding a dark brown material from which partially hydrolyzed hemicelluloses are easily recovered by water-washing, leaving a water-insoluble fraction composed of cellulose, residual hemicelluloses and a chemically modified lignin [20].

\section{FTIR spectra}

In order to understand the changes in the chemical structure after pretreatment, infrared spectra (Figure 4) of the untreated sample (A) and pretreated samples (B and C) were obtained. The assignments given to the absorption bands were referred to the collection of literature Table 1 [21-26].
The band at $1514 \mathrm{~cm}^{-1}$ has been chosen as an internal standard, since this band is present in all spectra and it is well defined.

The main features of these spectra are attributed to the presence of lignin, hemicellulose and cellulose; the natural components of lignocellulose fibers. Infrared spectra of pretreated samples are similar to the untreated ones, which show that the pretreatment conditions did not promote drastic changes in the chemical structure. The values in Tables 1, 2, 3 and 4 represent the relative absorbance of main functional groups stretching $(\mathrm{O}-\mathrm{H}, \mathrm{C}-\mathrm{Ph}, \mathrm{C}=\mathrm{C}$, $\mathrm{OCH}_{3}, \mathrm{C}=\mathrm{O}$ ).

The absorption at $2920 \mathrm{~cm}^{-1}$ could be attributed to $\mathrm{C}-\mathrm{H}$ aliphatic axial deformation in $\mathrm{CH}_{2}$ and $\mathrm{CH}_{3}$ groups from cellulose, lignin and hemicellulose.

Usually the absorptions of $\mathrm{O}-\mathrm{H}$ stretching occur in $3100-3600 \mathrm{~cm}^{-1}$ range. The band observed at $3386 \mathrm{~cm}^{-1}$ 


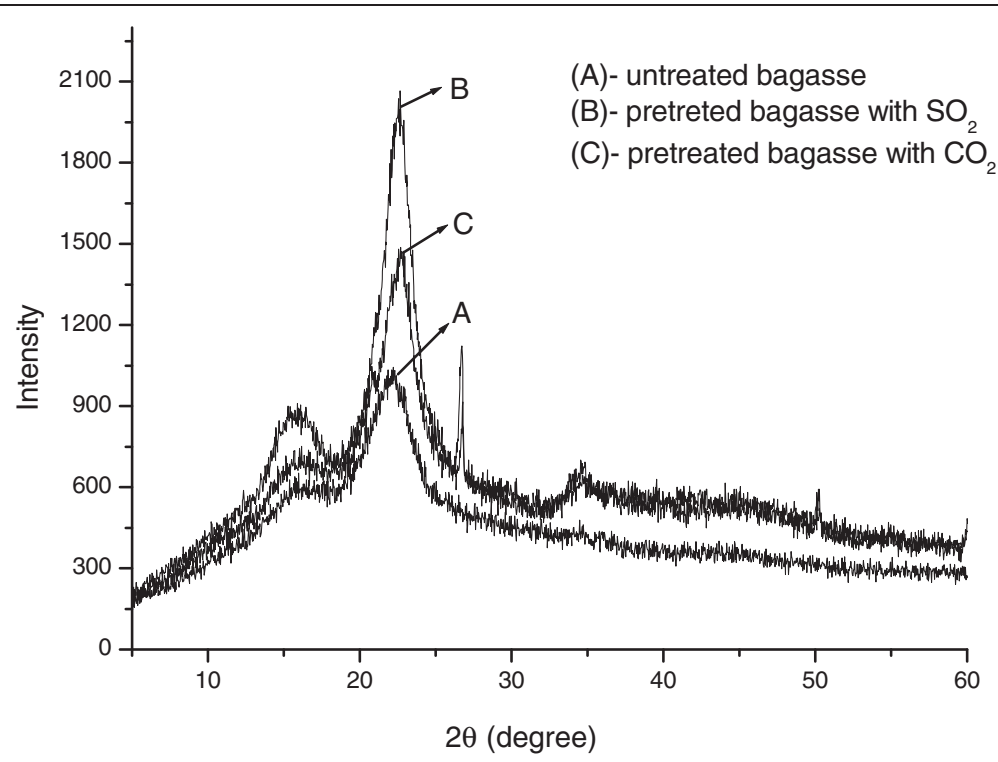

Figure 3 Diffractograms of the sugar cane bagasse samples: (A) untreated bagasse; (B) pretreated bagasse with $\mathrm{SO}_{2}\left(190^{\circ} \mathrm{C} / 5 \mathrm{~min}\right)$; (C) pretreated bagasse with $\mathrm{CO}_{2}\left(205^{\circ} \mathrm{C} / 15 \mathrm{~min}\right)$.

seems to be characteristic of $\mathrm{OH}$ groups present in lignin and carbohydrates. From Table 3, it could be observed that this band has higher values of relative absorbance in the case of pretreated samples when compared to untreated one. This result could be attributed to the chemical changes observed when sugar cane bagasse is pretreated with $\mathrm{SO}_{2}$ or $\mathrm{CO}_{2}$.

The relative absorbance of the bands of primary and secondary $\mathrm{OH}$ groups at $1051 \mathrm{~cm}^{-1}$ and $1165 \mathrm{~cm}^{-1}$ of untreated sugar cane bagasse is lower than the pretreated ones (Tables 1 and 3). It is worth noting that the relative absorbance of pretreated bagasse with $\mathrm{SO}_{2}$ is even higher than the one pretreated with $\mathrm{CO}_{2}$. This could be explained by the fact that $\mathrm{SO}_{2}$ provides a lower $\mathrm{pH}$ and consequently a higher combined severity, which resulted in a more exposed structure.

According to Nada and co-workers [13], the band at $2852 \mathrm{~cm}^{-1}$ is assignable to vibration of $\mathrm{OCH}_{3}$ groups, which is commonly present in lignin (Table 2). This $\mathrm{OCH}_{3}$ group could also be attributed to acetyl from

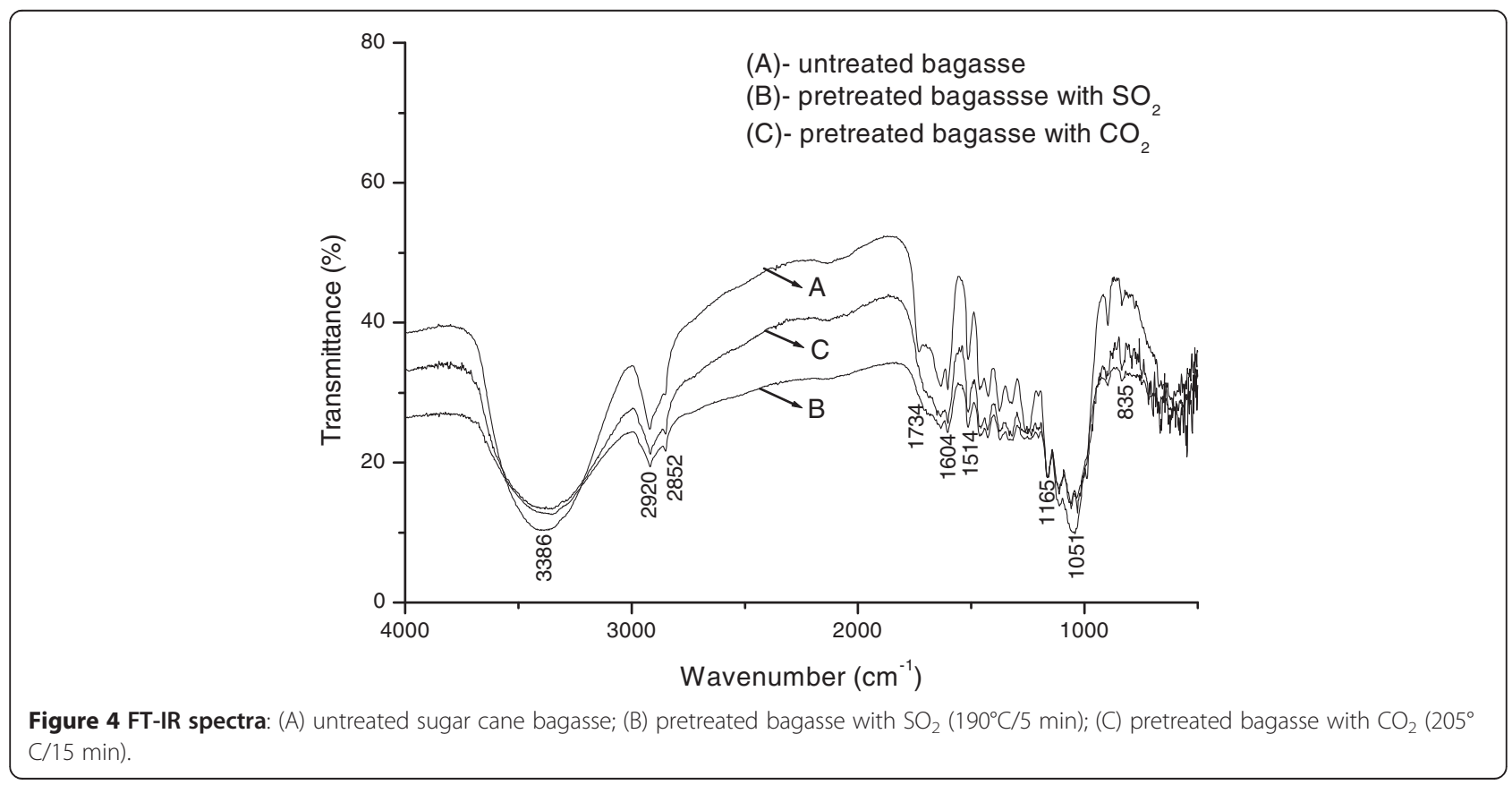


Table 1 Relative intensity of bands in the infrared spectrum of different groups in the untreated and pretreated sugar cane bagasse samples

\begin{tabular}{|c|c|c|c|c|}
\hline \multirow{2}{*}{$\begin{array}{l}\text { Assignment of } \\
\text { FT-IR absorption } \\
\text { of sugar cane } \\
\text { bagasse }\end{array}$} & \multicolumn{4}{|c|}{$\begin{array}{c}\text { Relative absorbance of different groups in } \\
\text { bagasse samples }\end{array}$} \\
\hline & $\begin{array}{c}\text { Maximum } \\
\text { band position } \\
\left(\mathrm{cm}^{-1}\right)\end{array}$ & $\begin{array}{l}\text { Untreated } \\
\text { bagasse }\end{array}$ & $\begin{array}{c}\text { Pretreated } \\
\text { bagasse with } \\
\mathrm{SO}_{2}\end{array}$ & $\begin{array}{c}\text { Pretreated } \\
\text { bagasse with } \\
\mathrm{CO}_{2}\end{array}$ \\
\hline $\begin{array}{l}\text { O-H stretching } \\
\text { (H-bonded) }\end{array}$ & 3386 & 0.30 & 0.51 & 0.50 \\
\hline $\begin{array}{l}\mathrm{O}-\mathrm{H} \text { vibration of } \\
\text { phenolic group }\end{array}$ & 1375 & 0.79 & 0.93 & 0.90 \\
\hline $\begin{array}{l}\text { O-H stretching of } \\
\text { secondary alcohol }\end{array}$ & 1165 & 0.51 & 0.71 & 0.65 \\
\hline $\begin{array}{l}\text { O-H stretching of } \\
\text { primary alcohol }\end{array}$ & 1051 & 0.29 & 0.61 & 0.57 \\
\hline C-O-C stretching & 1110 & 0.40 & 0.65 & 0.58 \\
\hline $\begin{array}{l}\text { C-O stretching } \\
\text { of phenols }\end{array}$ & 1250 & 0.69 & 0.95 & 0.89 \\
\hline $\begin{array}{l}\mathrm{C}-\mathrm{H} \text { aliphatic } \\
\text { axial deformation }\end{array}$ & 2920 & 0.71 & 0.78 & 0.78 \\
\hline $\begin{array}{l}\mathrm{C}-\mathrm{H} \text { aliphatic } \\
\text { angular } \\
\text { deformation }\end{array}$ & 1427 & 0.85 & 0.94 & 0.91 \\
\hline $\begin{array}{l}\mathrm{C}-\mathrm{H} \text { vibration } \\
\text { of methoxyl group }\end{array}$ & 2852 & 0.85 & 0.87 & 0.89 \\
\hline $\begin{array}{l}\mathrm{C}-\mathrm{H} \text { angular } \\
\text { deformation of } \\
\text { methoxyl group }\end{array}$ & 1462 & 0.88 & 0.95 & 0.93 \\
\hline C-Ph vibration & 1604 & 0.88 & 0.97 & 0.94 \\
\hline $\begin{array}{l}\mathrm{C}=\mathrm{C} \text { aromatic } \\
\text { skeletal vibration }\end{array}$ & 1633 & 0.89 & 0.99 & 0.98 \\
\hline $\begin{array}{l}\beta \text {-glycisidic } \\
\text { linkages }\end{array}$ & 897 & 1.14 & 1.24 & 1.19 \\
\hline $\mathrm{C}=\mathrm{O}$ stretching & 1735 & 1.03 & 1.19 & 1.24 \\
\hline
\end{tabular}

hemicellulose. It could be observed that only a slight increase of $6.5 \%$ and $5.5 \%$ of the relative absorbance of $\mathrm{OCH}_{3}$ groups after pretreatment using $\mathrm{SO}_{2}$ or $\mathrm{CO}_{2}$, respectively, as expected after an efficient pretreatment process.

When comparing the relative absorbance of the $\mathrm{OCH}_{3}$ group and $\mathrm{OH}$ group (Tables 2 and 3), it is possible to note that there was a significant increase in the relative absorbance after pretreatment of $\mathrm{OH}$ groups $(31.9 \%$ and 28.8\%, using $\mathrm{SO}_{2}$ and $\mathrm{CO}_{2}$ in the pretreatment,

Table 2 Relative absorbance of $\mathrm{OCH}_{3}$ group $\left(\mathrm{cm}^{-1}\right)$ according to the FTIR spectrum of the sugar cane bagasse

\begin{tabular}{lccc}
\hline $\begin{array}{l}\mathrm{OCH}_{\mathbf{3}} \text { group } \\
\text { bands }\left(\mathbf{c m}^{-1}\right)\end{array}$ & $\begin{array}{c}\text { Untreated } \\
\text { bagasse }\end{array}$ & $\begin{array}{c}\text { Pretreated } \\
\text { bagasse with } \mathrm{SO}_{\mathbf{2}}\end{array}$ & $\begin{array}{c}\text { Pretreated } \\
\text { bagasse with } \mathrm{CO}_{\mathbf{2}}\end{array}$ \\
\hline 2852 & 0.85 & 0.87 & 0.89 \\
1462 & 0.88 & 0.95 & 0.93 \\
1427 & 0.85 & 0.94 & 0.91 \\
Mean value & 0.86 & 0.92 & 0.91 \\
\hline
\end{tabular}

Table 3 Relative absorbance of O-H group $\left(\mathrm{cm}^{-1}\right)$ according to the FTIR spectrum of the sugar cane bagasse

\begin{tabular}{lccc}
\hline $\begin{array}{l}\text { OH group } \\
\text { bands }\left(\mathbf{c m}^{-1}\right)\end{array}$ & $\begin{array}{c}\text { Untreated } \\
\text { Bagasse }\end{array}$ & $\begin{array}{c}\text { Pretreated } \\
\text { bagasse with } \mathbf{S O}_{\mathbf{2}}\end{array}$ & $\begin{array}{c}\text { Pretreated } \\
\text { bagasse with } \mathbf{C O}_{\mathbf{2}}\end{array}$ \\
\hline 3386 & 0.3 & 0.51 & 0.50 \\
1375 & 0.79 & 0.93 & 0.90 \\
1165 & 0.51 & 0.71 & 0.65 \\
1051 & 0.29 & 0.61 & 0.57 \\
Mean value & 0.47 & 0.69 & 0.66 \\
\hline
\end{tabular}

respectively), while this is not observed for the $\mathrm{OCH}_{3}$ groups $\left(6.5 \%\right.$ and $5.5 \%$, using $\mathrm{SO}_{2}$ and $\mathrm{CO}_{2}$, respectively). This data indicate the conversion of lignin methoxyl groups into phenolic groups during pretreatment [25].

The bands at $1604 \mathrm{~cm}^{-1}$ and $1633 \mathrm{~cm}^{-1}$ are attributed to $\mathrm{C}-\mathrm{Ph}$ and $\mathrm{C}=\mathrm{C}$, respectively. These bands are generally found in the lignin aromatic structure. The relative absorbance of these vibrations are higher (around 9.3\%) after pretreatment (Table 4), which confirms the conversion of lignin methoxyl groups into phenolic groups.

The band at $1735 \mathrm{~cm}^{-1}$ is referred to the acetyl groups present in the hemicellulose. The pretreated bagasse with $\mathrm{CO}_{2}$ or $\mathrm{SO}_{2}$ exhibits a higher relative absorbance when compared to untreated sample $16.9 \%$ and $15.5 \%$, respectively (Table 1). The former results can be explained by the amount of hemicelullose fraction removed in each pretreatment, $40.5 \%$ and $63.7 \%$ for using $\mathrm{CO}_{2}$ and $\mathrm{SO}_{2}$, respectively [10].

The signal at $897 \mathrm{~cm}^{-1}$ is attributed to $\beta$-glycosidic linkages between monosaccharide units and it is also higher for the pretreated samples $\left(8.8 \%\right.$ and $4.4 \%$ with $\mathrm{SO}_{2}$ and $\mathrm{CO}_{2}$, respectively), as expect after bagasse fibers exposure.

\section{Conclusions}

The analysis by SEM, TEM, XRD and FTIR spectroscopy of steam pretreated bagasse in the presence of $\mathrm{CO}_{2}$ at $205^{\circ} \mathrm{C} / 15 \mathrm{~min}$ or $\mathrm{SO}_{2}$ at $190^{\circ} \mathrm{C} / 5 \mathrm{~min}$ showed significant differences amongst the untreated and the pretreated materials. It was observed in the outer region of the cell wall (SCW), upon pretreatment, the formation of large pores with different sizes and shapes which were more

Table 4 Relative absorbance of aromatic ring $\left(\mathrm{cm}^{-1}\right)$ according to the FTIR spectrum of the sugar cane bagasse

\begin{tabular}{lccc}
\hline $\begin{array}{c}\text { Aromatic ring } \\
\text { bands }\left(\mathbf{c m}^{-1}\right)\end{array}$ & $\begin{array}{c}\text { Untreated } \\
\text { Bagasse }\end{array}$ & $\begin{array}{c}\text { Pretreated } \\
\text { bagasse with } \mathbf{S O}_{\mathbf{2}}\end{array}$ & $\begin{array}{c}\text { Pretreated } \\
\text { bagasse with } \mathbf{C O}_{\mathbf{2}}\end{array}$ \\
\hline 1604 & 0.88 & 0.97 & 0.94 \\
1633 & 0.89 & 0.99 & 0.98 \\
Mean value & 0.88 & 0.98 & 0.96 \\
\hline
\end{tabular}


prominent when $\mathrm{SO}_{2}$ was the impregnating agent. It was also observed in both cases the formation, in the cell wall, of coalescent particles with round or elongated shapes likely formed by lignin and/or hemicellulose.

The morphology of $\mathrm{CO}_{2}$-pretreated bagasse was more preserved than that of the $\mathrm{SO}_{2}$-preatrement, likely due to its lower combined severity factor of 0.9 in comparison to that of $\mathrm{SO}_{2-}$ pretreatment of 1.7. It was also observed that both impregnating agents, $\mathrm{SO}_{2}$ or $\mathrm{CO}_{2}$, behaved in a quite similar way.

The crystallinity index values obtained from XRD patterns showed that pretreated materials have higher values $\left(\mathrm{CI}\left(\mathrm{SO}_{2}\right)=65.5 \%\right.$, $\left.\mathrm{CI}\left(\mathrm{CO}_{2}\right)=56.4 \%\right)$ when compared with untreated material $(\mathrm{CI}=42.5 \%)$, due to the partial removal from the bagasse of its hemicelluloses content. The results of FTIR spectra also showed changes in the chemical structure of materials pretreated with $\mathrm{CO}_{2}$ and $\mathrm{SO}_{2}$, mainly in $\mathrm{OCH}_{3}, \mathrm{OH}$ and $\mathrm{C}=\mathrm{O}$ groups; which supported the data from the XRD, SEM and TEM analysis.

\section{Methods}

The use of $\mathrm{SO}_{2}$ and $\mathrm{CO}_{2}$ as an impregnating agent for sugar cane bagasse treatment was previously studied [10]. In the present study the most promising pretreated materials were selected for further studies on structural modifications. Bagasse samples steam pretreated in the presence of $\mathrm{CO}_{2}\left(205^{\circ} \mathrm{C} / 15 \mathrm{~min}\right)$ and $\mathrm{SO}_{2}\left(190^{\circ} \mathrm{C} / 5 \mathrm{~min}\right)$ and also untreated bagasse were submitted to the following techniques: electron microscopy, X-ray diffraction and infrared spectroscopy. All samples were sieved $(<1.8 \mathrm{~mm})$ before analyses.

\section{Scanning electron microscopy (SEM)}

Scanning electron microscopy (SEM - FEI / Inspect S50 model) was used to observe modifications on bagasse fibers. Samples were adhered to carbon tape and sputter coated with gold (sputter Emitech / K550 model) and observed in the SEM through the use of an acceleration voltage of 20 $\mathrm{KV}$ and working distance of around $38 \mathrm{~mm}$. Hundreds of SEM images were obtained on different areas of the samples to guarantee the reproducibility of the results.

\section{Transmission electron microscopy (TEM)}

Transmission electron microscopy (FEI Tecnai G2 12 Spirit) was used to observe the ultrastructural changes within the cell wall. Each condition (untreated material, pretreated with $\mathrm{SO}_{2}$ and $\mathrm{CO}_{2}$ material) was analyzed in triplicate. Each individual sample was studied by an unbiased random selection of fibers that represent the total population. Samples were dehydrated in an increasing acetone series and embedded in Spurr resin. Ultrathin sections, $70 \mathrm{~nm}$, were obtained in the LEICA ultramicrotome and deposited onto copper grids. The sections were stained with $5 \%$ uranyl acetate and lead citrate and observed in the TEM with an acceleration voltage of $120 \mathrm{kV}$.

\section{X-ray diffraction (XRD)}

Crystallinity of the cellulose fibers was evaluated by Xray diffraction by means of a Diffractometer MiniFlex Rigaku and filtered copper $K \alpha$ radiation $(\lambda=0,1542 \mathrm{~nm})$ by a monochromator at $30 \mathrm{KV}$ voltage and $15 \mathrm{~mA}$ electric current, with a speed of about 2 degrees per minute and scanning at an angle $(2 \theta)$ in the range of $2-60$. The crystallinity of lignocellulose biomass accounts for the relative amount of total crystalline cellulose in the solid component. The crystallinity is strongly influenced by the composition of biomass; the relative amount of lignin, hemicellulose and cellulose varies according to the nature of the biomass. The crystallinity index (CI) was obtained from the ratio between the intensity of the 002 peak $\left(\mathrm{I}_{002}, 2 \theta=22.5\right)$ and the minimum $\operatorname{dip}\left(\mathrm{I}_{\mathrm{am}}, 2 \theta=18.5\right)$ between the 002 and the 101 peaks according to Equation $1[14,27]$.

$$
\% C I=\left[\left(I_{002}-I_{a m}\right) / I_{002}\right] \times 100
$$

Where $I_{002}$ is the intensity of plane 002 and $I_{a m}$ is related to the amorphous structure.

\section{Infrared spectroscopy (FTIR)}

The infrared spectra (wave numbers in $\mathrm{cm}^{-1}$ ) were obtained on a Magma - IR 560 E.S.P - Nicolet spectrophotometer, by means of a $\mathrm{KBr}$ disk containing $3 \%$ finely ground samples. Thirty-two scans were taken of each sample recorded from 4000 to $400 \mathrm{~cm}^{-1}$ at a resolution of $4 \mathrm{~cm}^{-1}$. The relative absorbance values were obtained with four decimal units; however, only two decimal units were plotted in the data showed in Tables 1, 2, 3 and 4.

\section{Abbreviations}

FTIR: Fourier transform infrared spectroscopy; SEM: Scanning electron microscopy; TEM: Transmission electron microscopy; XRD: X-Ray diffraction spectroscopy; Cl: Crystallinity index.

\section{Competing interests}

The authors declare that they have no competing interests.

\section{Acknowledgement}

Authors would like to thank the Brazilian Innovation Agency - (FINEP), the Ministry of Science, Technology and Innovation (MCTI) and the Brazilian Council for Research and Development (CNPq) for financial support. Authors are also thankful to Prof. Guido Zacchi and colleagues from the Chemical Engineering Department, Lund University. Authors would like to express their gratitude to colleagues from CENANO/INT/MCTI (Center of Nanostructure Characterization), especially to Sheyla Santana de Carvalho and Fernanda C.S.C. dos Santos.

\section{Author details}

${ }^{1}$ National Institute of Techonology, Ministry of Science and Techonology, Av. Venezuela, 82, sala 302, CEP 20081-312 Rio de Janeiro - RJ, Brazil. ${ }^{2}$ National Institute of Metrology, Standardization and Industrial Quality, Av. Nossa Senhora das Graças, 50 - Xerém, CEP 25250-020 Duque de Caxias - RJ, Brazil. ${ }^{3}$ National Institute of Science and Technology in Structural Biology and Bioimagens, Federal University of Rio de Janeiro, Av. Pedro Calmon, 550, 
Prédio da Reitoria - sala 801, llha do Fundão - CEP 21941-901, Rio de Janeiro - RJ, Brazil. ${ }^{4}$ Department of Biochemistry, Institute of Chemistry, Federal University of Rio de Janeiro, Av. Athos da Silveira Ramos, 149, bloco A, llha do Fundão, CEP: 21941-909 Rio de Janeiro - RJ, Brazil.

\section{Authors' contributions}

$V L$ and CP designed and carried out the experiments of pretreatment, the characterization of biomass, the discussion of results and revision of the manuscript. RC carried out SEM and XRD experiments and prepared the manuscript. FM carried out FTIR spectroscopy experiments and analyzed the results. CS and YA performed TEM analysis and discussed the results. EB and WS discussed the results and reviewed the manuscript. All authors read and approved the final version of the manuscript.

Received: 13 February 2012 Accepted: 22 May 2012

Published: 22 May 2012

\section{References}

1. Mohanty AK, Misra M, Drzal LT: Sustainable biocomposites from renewable resources: Opportunities and challenges in the green materials world. J Polymer Environ 2002, 10:19-26.

2. Taherzadeh MJ, Karimi K: Enzymatic-based hydrolysis processes for ethanol from lignocellulosic materials: A review. Bioresource 2007, 2:707-738.

3. UNICA: Brazilian Sugarcane Industry Association. http://www.unica.com.br/.

4. Pandey A, Soccol CR, Nigam P, Soccol VT: Biotechnological potential of agroindustrial residues. I. Sugarcane bagasse. Bioresour Techno/ 2000, 74:69-80.

5. Richardson S, Gorton L: Characterisation of the substituent distribution in starch and cellulose derivatives. Anal Chim Acta 2003, 497:27-65.

6. Fengel D, Wegener G: Wood: chemistry, ultrastructure, reactions. XII. Berlin, New York: Walter de Gruyter; 1989.

7. Zhang YHP, Lynd LR: Toward an aggregated understanding of enzymatic hydrolysis of cellulose: Noncomplexed systems. Biotechnol Bioeng 2004, 88:797-824.

8. Yang B, Wyman CE: Pre-treatment: the key to unlocking low-cost cellulosic ethanol. Biofuels Bioprod Bioref 2008, 2:26-40.

9. Galbe M, Zacchi G: Pretreatment of Lignocellulosic Materials for Efficient Bioethanol Production. Adv Biochem Eng Biotechnol 2007, 108:41-67.

10. Ferreira-Leitão V, Perrone CC, Rodrigues J, Franke APM, Macrelli S, Zacchi G. An approach to the utilisation of $\mathrm{CO}_{2}$ as impregnating agent in steam pretreatement of sugar cane bagasse and leaves for ethanol production. Biotechonol Biofuels 2010, 3:1-8.

11. Perrone CC, Zacchi G: Processo para o pré-tratamento de biomassa lignocelulósica. Patent number (BR 0803354-4). Brazil: 2008.

12. Rezende CA, Lima MA, Maziero P, Azevedo ER, Garcia W, Polikarpov I: Chemical and morphological characterization of sugarcane bagasse submitted to a delignification process for enhanced enzymatic digestibility. Biotechonol Biofuels 2011, 4:54.

13. Nada AAMA, El-Sakhawy M, Kamel SM: Infra-red spectroscopic study of lignins. Polymer Degrad Stability 1998, 60:247-251.

14. Rodrigues Filho G, De Assunção RMN, Vieira JG, Meireles CS, Cerqueira DA, Barud HS, Ribeiro SJL, Messaddeq Y: Characterization of methylcellulose produced from sugar cane bagasse cellulose: Crystallinity and thermal properties. Polymer Degrad Stability 2007, 92:205-210.

15. Chundawat SPS, Donohoe BS, Sousa LC, Elder T, Agarwal UP, Lu F, Ralph J, Himmel ME, Balan V, Dale BE: Multi-scale visualization and characterization of lignocellulosic plant cell wall deconstruction during thermochemical pretreatment. Energy Env Sci 2011, 4:973-984.

16. Grethlein HE: The effect of pore size distribution on the rate of enzymatic hydrolysis of cellulosic substrates. BioTechnol 1985, 3:155-160.

17. Donohoe BS, Selig MJ, Viamajala S, Vinzant TB, Adney WS, Himmel ME: Detecting cellulase penetration into corn stover cell walls by immunoelectron microscopy. Biotechnol Bioeng 2009, 103:480-489.

18. Chum H, Johnson DK, Black SK: Organosolv pretreatment for enzymic hydrolysis of poplars. 2. Catalyst effects and the combined severity parameter. Ind Eng Chem Res 1990, 29:156-162.

19. Tanahashi M, Takada S, Aoki GT, Higuchi T, Hanai S: Characterization of explosion Wood.1. Structure and physical properties. Wood Res 1983, 9:31-36.

20. Ramos LP: The Chemistry involved in the steam treatment of lignocellulosic materials. Quim Nova 2003, 26:863-871.
21. Gastaldi G, Capretti G, Focher B, Cosentino C: Characterization and properties of cellulose isolated from the crambe abyssinica hull. Ind Crop Prod 1998, 8:205-218.

22. Li M-F, Yong-Ming F, Run-Cang S, Xu Feng: Characterization of extracted lignin of bamboo (Neosinocalamus affinis) pretreated with sodium Hydroxide/urea solution at low temperature. BioResour 2010, 5:1762-1778.

23. Shao SL, Wen GF, Jin ZF: Changes in chemical characteristics of bamboo (Phyllostachys pubescens) components during steam explosion. Wood Sci Techonol 2008, 42:439-451.

24. Faix O: Classification of lignins from different botanical origins by FT-IR spectroscopy. Holzforschung 1991, 45:21-27.

25. Pretsch E, Clerc S, Simon R: Tables of Spectra Data for Structure Determination of Organic Compounds, Chem Lab Prat. 2nd edition. London: Springer-Verlag; 1989.

26. Silverstein RM, Webster FX: Identificação Espectrométrica de Compostos Orgânicos. 6th edition. Brazil: LTC; 2000.

27. Segal L, Creely JJ, Martin AE, Conrad CM: An Empirical Method for Estimating the Degree of Crystallinity of Native Cellulose Using the X-Ray Diffractometer. Text Res J 1959, 29:764-786.

doi:10.1186/1754-6834-5-36

Cite this article as: Corrales et al:: Structural evaluation of sugar cane bagasse steam pretreated in the presence of $\mathrm{CO}_{2}$ and $\mathrm{SO}_{2}$. Biotechnology for Biofuels 2012 5:36.

\section{Submit your next manuscript to BioMed Central and take full advantage of:}

- Convenient online submission

- Thorough peer review

- No space constraints or color figure charges

- Immediate publication on acceptance

- Inclusion in PubMed, CAS, Scopus and Google Scholar

- Research which is freely available for redistribution 